\title{
ПОКАЗНИКИ ЕНДОГЕННОЇ ІНТОКСИКАЦІЇ У ЩУРІВ ПРИ ДОБРОЯКІСНІЙ ГІПЕРПЛАЗІЇ ПРОСТАТИ НА ТЛІ ТОКСИЧНОЇ ДІЇ ЕТАНОЛУ
}

Вступ. Доброякісна гіперплазія простати серед урологічних захворювань чоловіків старшого віку посідає вагоме місце з тенденцією до зростання. Найпоширенішою соціальною проблемою є вживання алкоголю. Його токсичної дії зазнає багато систем та органів, адже він легко взаємодіє з багатьма процесами життєдіяльності організму. За рахунок синдрому ендогенної інтоксикації ми можемо оцінити багато даних та отримати результати про перебіг багатьох захворювань за рівнем молекул середньої маси та змінами еритроцитарного індексу.

Мета дослідження - вивчити зміни показників ендогенної інтоксикації за рівнем молекул середньої маси та змінами еритроцитарного індексу в щурів з доброякісною гіперплазією простати при поєднаній дії етанолу.

Методи дослідження. Експериментальних тварин поділили на 4 групи: 1-ша (контрольна) - щури, яким протягом 28 діб вводили дистильовану воду перорально; 2-га - тварини, яким упродовж 28 днів вводили 40 \% розчин етанолу з розрахунку 2 мл/100 г маси тіла внутрішньошлунково 1 раз на добу; 3-тя щури, яким моделювали розвиток доброякісної гіперплазії передміхурової залози шляхом підшкірного введення ампульного 5 \% тестостерону в дозі 0,1 мг/ка 1 раз на добу тривалістю 28 діб; 4-та - тварини, в яких відтворювали модель доброякісної гіперплазії передміхурової залози з додатковим токсичним впливом 40 \% розчину етанолу з розрахунку 2 мл/100 г маси тіла внутрішньошлунково 1 раз на добу тривалістю 28 діб.

Результати й обговорення. У результаті досліджень, які ми провели у тварин різних дослідних груп за умов експериментального моделювання доброякісної гіперплазії простати, встановлено, що відбувається поступове зростання показників ендогенної інтоксикації на 7-му, 14-ту, 21-шу доби експерименту. Найвищих показників усі маркери ендогенної інтоксикації досягли на 21-шу добу дослідження.

Висновок. Ми змогли встановити значні зміни і порушення процесів інтоксикації у тварин під токсичною дією етанолу, що має важливе значення для їх патогенезу.

КЛЮЧОВІ СЛОВА: етанол; ендогенна інтоксикація; доброякісна гіперплазія простати.

ВСТУП. Захворюванням передміхурової залози у чоловіків, найбільш асоційованим 3 віком, $є$ доброякісна гіперплазія передміхурової залози (ДГПЗ). На основі багатьох спостережень встановлено пряму залежність між частотою випадків її розвитку та віковим фрактором. В останні роки до цієї проблеми прикута увага багатьох спеціалістів, і вона все більше виходить за межі однієї урології [1-3].

Як у минулому, так і на сьогодні найпоширенішою соціальною проблемою є вживання алкоголю. Його токсичної дії зазнає багато систем та органів, адже він легко взаємодіє з багатьма процесами життєдіяльності організму, спричиняючи тим самим розлади внутрішньоклітинного обміну та прояви інтоксикаційного синдрому. ๑ Ю. І. Макодрай, І. М. Кліщ, 2021.
В багатьох джерелах наукової літератури описують різні ушкодження, викликані етанолом: порушення в імунній та гормональній системах, зміни обміну і синтезу білків, ліпідів, нейромодуляторів, порушення енергоутворення, окисно-відновних процесів та ушкодження мембран. Виникає так звана біологічна залежність, що формує особливий "алкогольний" тип гомеостазу $[4,5]$.

На сьогодні ми можемо оцінити багато даних та отримати результати про перебіг багатьох захворювань за рахунок універсального патофізіологічного синдрому - синдрому ендогенної інтоксикації. Він розвивається в результаті впливу багатьох зовнішніх та внутрішніх фоктторів середовища. Ендогенна інтоксикація (ЕІ) виникає через надмірне накопичення продуктів як 
порушеного, так і нормального обміну речовин, що чинять токсичний вплив на клітини і тканини та призводять до поглиблення і погіршення патологічних процесів в організмі, погіршення перебігу захворювання. До найважливіших показників EI належать молекули середньої маси (MCM), еритроцитарний індекс інтоксикації (EII), циркулюючі імунні комплекси (ЦІК) $[6,7]$. На думку багатьох авторів, зростання рівня МСМ є найчутливішим маркером ендогенної інтоксикації, а підвищення EII означає збільшення проникності мембран організму, що проявляється їх цитолізом. Стан гуморальної ланки імунної системи організму характеризує рівень ЦІК [810].

Мета дослідження - вивчити зміни показників ендогенної інтоксикації за рівнем молекул середньої маси та змінами еритроцитарного індексу в щурів з доброякісною гіперплазією простати при поєднаній дії етанолу.

МЕТОДИ ДОСЛІДЖЕННЯ. Для дослідження перебігу ДГПЗ за умов впливу етанолу експеримент проводили на 48 статевозрілих щурах-самцях лінії Вістар масою від 190 до 250 г включно, вирощених у віварії Центральної науково-дослідної лабораторії Тернопільського національного медичного університету імені І. Я. Горбачевського МОЗ України. Відповідно до Європейської конвенції про захист хребетних тварин, що використовуються для дослідних та інших наукових цілей (Страсбург, 1986, зміни, внесені в 1998 р.), Загальних етичних принципів експериментів на тваринах, усі процедури та маніпуляції зі щурами було проведено з дотриманням національних та міжнародних рекомендацій. Комісія з біоетики Тернопільського національного медичного університету імені І. Я. Горбачевського МО3 України встановила, що при виконанні цього дослідження біоетичні норми не були порушені.

Лабораторних тварин поділили на 4 групи: 1-ша (контрольна) - 12 інтактних щурів, яким протягом 28 діб вводили дистильовану воду перорально; 2-га - 12 тварин, яким упродовж 28 діб вводили 40 \% розчин етанолу з розрахунку 2 мл/100 г маси тіла внутрішньошлунково 1 раз на добу; 3-тя - 12 щурів, у яких моделювали розвиток ДГПЗ шляхом підшкірного введення 5 \% олійного розчину тестостерону в дозі 0,1 мг/кг 1 раз на добу тривалістю 28 діб та які споживали дистильовану воду протягом цього ж часу; 4-та - 12 тварин, в яких відтворювали модель ДГПЗ із додатковим токсичним впливом 40 \% розчину етанолу з розрахунку 2 мл/100 г маси тіла внутрішньошлунково 1 раз на добу тривалістю 28 діб.
Дані дослідних груп порівнювали 3 даними контрольної групи на 7-му, 14-ту і 21-шу доби.

Ступінь вираження ендогенної інтоксикації оцінювали за вмістом у сироватці крові молекул середньої маси та циркулюючих імунних комплексів, а також показником еритроцитарного індексу інтоксикації. Отримані результати опрацьовували статистично - обчислювали середню арисрметичну варіаційного ряду (М), стандартну похибку середньої арифрметичної (m) та достовірність відмінностей (р).

Вміст МСМ визначали у сироватці крові за методом Н. І. Габриеляна у модифрікації В. К. Осиповича та співавт. Обробляли 1 мл сироватки крові 0,6 Н розчином трихлороцтової кислоти, центрисругували, оптичну щільність вимірювали при довжині хвилі 254 нм на спектрофротометрі (СФ-46) [6, 11]. Еритроцитарний індекс інтоксикації досліджували за допомогою методу В. К. Казимирка [12]. Концентрацію ЦІК у сироватці крові визначали за методом Хашкова [13].

РЕЗУЛЬТАТИ Й ОБГОВОРЕННЯ. ПрИ баГатьох патологічних станах, у результаті накопичення великої кількості продуктів метаболізму, що токсично впливають на організм у цілому, розвивається синдром ендогенної інтоксикації, який проявляється збільшенням різної кількості маркерів ендогенної інтоксикації, в тому числі зростанням показників МСM та ElI.

Моделювання доброякісної гіперплазії простати, а особливо на тлі етанолової інтоксикації, супроводжувалось виразним підвищенням показників ендотоксикозу. Зокрема, спостерігали збільшення вмісту $\mathrm{MCM}_{1}$ і $\mathrm{MCM}_{2}$, починаючи вже із 7-го дня експерименту, з тенденцією до зростання до 21-ї доби в усіх дослідних групах. Максимальні значення на 21-шу добу $\mathrm{MCM}_{1}$ та $\mathrm{MCM}_{2}$ отримали в 4-й групі піддослідних тварин. Порівняно зі щурами, яким патологічного процесу не моделювали (1-ша група), показник $\mathrm{MCM}_{1}$ підвищився на 42,78 \%. Дещо менше зростання спостерігали стосовно показників 2-ї групи - на 18,18 \%, а порівняно 3 3-ю дослідною групою збільшення становило 13,69\%. Аналогічні зміни відзначали і щодо $\mathrm{MCM}_{2}$. Відносно тварин без змодельованої патології підвищення в 4-й групі становило 58,2 \%. Це означає, що при тривалій токсичній дії етанолу на організм щурів накопичуються продукти обміну, нормального або порушеного, які спричиняють диссрункцію різних регуляторних систем організму.

Про наростання показників EI при моделюванні ДГПЗ без алкогольного чинника та з впливом етанолу на залозу свідчили дані щодо вмісту МСМ на двох максимумах хвиль із 7-ї доби 
експерименту, що підтвердило односпрямованість їх змін.

Еритроцитарний індекс інтоксикації в 4-й дослідній групі (ДГПЗ+етанолова інтоксикація) на 7-му добу зріс на 72,54 \% ( $<<0,03)$, на 14-ту на 75,03\% (p<0,001), на 21-шу - на 84,7\% $(p<0,001)$ порівняно з контрольною групою. У цій же групі показники ЕI також підвищились відносно 3-ї дослідної групи (ДГПЗ без токсичного чинника) - на 12,91 \% ( $<<0,02), 7,83 \%(p<0,05)$, $40,07 \%(p<0,001)$ на 7-му, 14-ту, 21-шу доби відповідно.

Зростання показників системи гуморального імунітету як індикатора, що вказує на високу чутливість імунітету до патологічного процесу в простаті, вивчали в усіх 4 групах піддослідних тварин. Циркулюючі імунні комплекси утворюються у відповідь на дію чужорідних антигенів, що надходять ззовні, або ж автоантигенів, які утворюються в процесі життєдіяльності організму чи при різних патологічних станах. Такі комплекси відкладаються на мембранах судин і накопичуються безпосередньо у тканинах з індукцією локального запалення та ушкодження тканин органів. Істотне збільшення рівня ЦІК ми відмітили вже у 2-й дослідній групі щурів, які споживали 40 \% етанол щодня протягом експерименту. Порівняно з контрольною групою тварин уже на початку експерименту (7-ма доба) показники підвищились на 17,37 \%, а до 21-ї доби зросли до 44,24 \%. Вміст ЦІК у крові тварин, яким моделювали ДГПз без етанолової інтоксикації, збільшився на 21-шу добу на 45,88 \% відносно 2-ї групи. У тварин 4-ї групи зростання вмісту ЦІК було істотно вищим, ніж у 1-й контрольній групі, а саме $67,53,104,7$ та $115,15 \%$ відповідно на 7-му, 14-ту і 21-шу доби спостереження ( $p<0,001)$ (табл.).

Таблиця - Показники ендотоксикозу в щурів з доброякісною гіперплазією передміхуророї

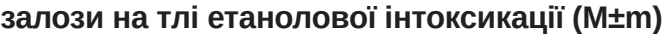

\begin{tabular}{|c|c|c|c|c|c|}
\hline \multirow{2}{*}{\multicolumn{2}{|c|}{ Група тварин }} & \multicolumn{4}{|c|}{ Показник } \\
\hline & & Ell, \% & $\begin{array}{c}\mathrm{MCM}_{1} \\
\text { ум. од. екст. }\end{array}$ & $\begin{array}{c}\text { МCM }_{2} \\
\text { ум. оД. екст. }\end{array}$ & $\begin{array}{c}\text { ЦІК, } \\
\text { ум. од./г }\end{array}$ \\
\hline \multicolumn{2}{|c|}{ Без патології, n=12 } & $30,92 \pm 0,21$ & $0,472 \pm 0,023$ & $0,214 \pm 0,011$ & $287,7 \pm 7,4$ \\
\hline \multirow[t]{3}{*}{\begin{tabular}{|l|} 
Етанолова \\
інтоксикація
\end{tabular}} & $\begin{array}{c}\text { 7-ма доба, } \\
\text { n=12 }\end{array}$ & $43,87 \pm 0,45^{\star}$ & $0,644 \pm 0,052^{*}$ & $0,335 \pm 0,012^{*}$ & $337,7 \pm 5,8^{*}$ \\
\hline & $\begin{array}{c}\text { 14-та доба, } \\
n=12\end{array}$ & $40,32 \pm 0,48^{*}$ & $0,522 \pm 0,056^{*}$ & $0,241 \pm 0,009^{*}$ & $342,2 \pm 4,9^{*}$ \\
\hline & $\begin{array}{c}\text { 21-ша доба, } \\
n=12\end{array}$ & $45,68 \pm 0,63^{*}$ & $0,675 \pm 0,061^{*}$ & $0,362 \pm 0,013^{*}$ & $415,0 \pm 6,4^{*}$ \\
\hline \multirow[t]{3}{*}{ ДГПЗ } & $\begin{array}{c}\text { 7-ма доба, } \\
\text { n=12 }\end{array}$ & $49,33 \pm 0,59 *$ & $0,688 \pm 0,063^{*}$ & $0,438 \pm 0,010^{*}$ & $444,0 \pm 7,3^{\star}$ \\
\hline & $\begin{array}{c}\text { 14-та доба, } \\
\text { n=12 }\end{array}$ & $51,70 \pm 0,60^{*}$ & $0,714 \pm 0,066^{*}$ & $0,359 \pm 0,015^{*}$ & $449,0 \pm 6,9^{*}$ \\
\hline & $\begin{array}{c}\text { 21-ша доба, } \\
n=12\end{array}$ & $44,72 \pm 0,57^{*}$ & $0,712 \pm 0,064^{*}$ & $0,443 \pm 0,018^{*}$ & $547,0 \pm 7,0^{*}$ \\
\hline \multirow[t]{3}{*}{$\begin{array}{l}\text { ДГПЗ+етанолова } \\
\text { інтоксикація }\end{array}$} & $\begin{array}{c}\text { 7-ма доба, } \\
\text { n=12 }\end{array}$ & $53,35 \pm 0,74^{* \#}$ & $0,725 \pm 0,065^{\star}$ & $0,450 \pm 0,016^{* \#}$ & $482,0 \pm 8,3^{\star \#}$ \\
\hline & $\begin{array}{c}\text { 14-та доба, } \\
\text { n=12 }\end{array}$ & $54,12 \pm 0,80^{*}$ & $0,659 \pm 0,067^{\star \#}$ & $0,470 \pm 0,017^{\text {*\# }}$ & $589,0 \pm 8,9^{\text {*\# }}$ \\
\hline & $\begin{array}{c}\text { 21-ша доба, } \\
\text { n=12 }\end{array}$ & $57,11 \pm 0,92^{\star \#}$ & $0,825 \pm 0,071^{\text {*\# }}$ & $0,512 \pm 0,019^{* \#}$ & $619,0 \pm 8,1^{\text {*\# }}$ \\
\hline
\end{tabular}

Примітки:

1. * - зміни достовірні відносно 1-ї групи тварин (без патології).

2. *\# - зміни достовірні відносно 3-ї групи тварин.

ВИСНОВКИ. 1. Результати проведених досліджень показали, що у тварин різних дослідних груп за умов експериментального моделювання доброякісної гіперплазії простати відбувалось поступове зростання показників ендогенної інтоксикації - молекул середньої маси, еритроцитарного індексу інтоксикації та циркулюючих імунних комплексів. Найвищих показників усі маркери ендогенної інтоксикації досягли на 21-шу добу експерименту, що можна пояснити їх надлишковим накопиченням і утворенням в органі-мішені з розвитком у ньому запального процесу.

2. Тривалий токсичний вплив етанолу на організм піддослідних тварин також призвів до зростання рівня маркерів ендотоксикозу. Найбільш виразними були зміни рівня циркулюючих імунних комплексів. Ці комплекси найкраще характеризують стан гуморальної ланки імунітету, а також мають важливе значення в патогене- 
зі гострих запальних процесів в організмі, $є$ показниками перебігу захворювань і есрективності проведеного лікування. Відповідно до результатів нашого дослідження, рівень циркулюючих імунних комплексів підвищився в динаміці з 7-ї до 21-ї доби, що свідчить про активацію гуморальної ланки імунітету і показує розлад імун- ного гемостазу, зокрема дисфункцію ретикулоендотеліальної системи.

3. Найбільш виразні зміни спостерігали у тварин, яким ДГПЗ моделювали на тлі етанолової інтоксикації. Показники ендотоксикозу були достовірно вищими, ніж у тварин з ДГПЗ, в усі терміни спостереження.

\section{СПИСОК ЛІТЕРАТУРИ}

1. Яковлєва Л. В. Доброякісна гіперплазія передміхурової залози, діагностика і лікування (огляд літератури) / Л. В. Яковлєва, Н. Я. Музика // Клініч. фрармація. - 2009. - 13, № 4. - С. 66-70.

2. Романюк А. М. Морфогенез передміхурової залози щурів у віковому аспекті / А. М. Романюк, О. А. Шкрьоба // Укр. морфол. альм. - 2014. - 12, № 2. - C. 79-81.

3. Mobley D. Benign prostatic hyperplasia and urinary symptoms: Evaluation and treatment / D. Mobley, A. Feibus, N. Baum // Postgrad. Med. - 2015. - 127. - P. 301307. DOI: 10.1080/00325481.2015.1018799

4. Харченко О. Токсична дія етанолу та його продуктів на організм / О. Харченко, Г. Гавриш, Л. Остапченко // Вісн. НАН України. - 2006. - № 3. - С. 57-64.

5. Волошина І. С. Сучасні уявлення про морфогенез внутрішніх органів чоловічої статевої системи під дією різних фракторів / І. С. Волошина // Укр. морфол. альм. - 2011. - 9, № 4. - С. 155-160.

6. Показники ендогенної інтоксикації у хворих на хронічний гнійний верхньощелепний синусит із цукровим діабетом 1-го типу / О. О. Мазур, О. А. Оленович, О. Г. Плаксивий [та ін.] // Буковин. мед. вісн. - 2017. 21, № 1 (81). - С. 76-80.

7. Кліщ І. М. Показники ендогенної інтоксикації та гуморального імунітету у тварин при хронічному простатиті й доброякісній гіперплазії на фоні одночасного впливу токсичного ксенодермального екстракту /

\section{REFERENCES}

1. Yakovlyeva, L.V., \& Muzyka, N.Ya. (2009). Benign prostatic hyperplasia, diagnosis and treatment (literature review). Clinical Pharmacy, 13 (4), 66-70 [in Ukrainian].

2. Romanyuk, A.M., \& Shkrobav, O.A. (2014). Morphogenesis of the prostate gland of rats in the age aspect. Ukrainian Morphological Almanac, 12 (2), 79-81 [in Ukrainian].

3. Mobley, D., Feibus, A., \& Baum, N. (2015). Benign prostatic hyperplasia and urinary symptoms: Evaluation and treatment. Postgrad. Med., 127, 301-307. DOI: 10.1080/00325481.2015.1018799

4. Kharchenko, O., Ostapchenko, H., \& Havrysh, L. (2006). Toxic effect of ethanol and its products on the body. Bulletin of the NAS of Ukraine, 3, 57-64 [in Ukrainian].
І. М. Кліщ, В. Я. Хорош // Мед. хімія. - 2013. - 15, № 1. - С. 125-129.

8. Лис О. Б. Ступінь ендогенної інтоксикації в динаміці розвитку поєднаної патології - іммобілізаційного стресу та адреналінового ушкодження міокарда / О. Б. Лис, М. С. Регеда // Вісн. наук. дослідж. 2019. - № 1. - С. 131-134.

9. Хохлова Н. И. Многофакторная клинико-лабораторная оценка эндогенной интоксикации при хроническом гепатите В / Н. И. Хохлова, Н. П. Толоконская, А. Б. Пупышев // Бюлл. сибирской медицины. 2011. - № 3. - С. 139-145.

10. Лабораторная диагностика синдрома эндогенной интоксикации : метод. рек. / М. В. Аксенова, В. Ф. Кузнецов, Ю. Н. Маслов [и др.]. - Пермь : ПГМА, 2005. - 39 c.

11. Волчегорский И. А. "Средние молекулы" как вероятные регуляторы системы эритрона у спортсменов-лыжников / І. А. Волчегорский, Д. А. Дятлов, Е. И. Львовская // Физиология человека. - 1996. - 22, № 3. - С. 136-137.

12. Казимирко В. К. Антиоксидантная система и ее функционирование в организме человека / В. К. Казимирко, В. И. Мальцев // Здоров'я України. - 2007. № 5. - С. 15-24.

13. Дранник Г. Н. Клиническая иммунология и аллергология / Г. Н. Дранник. - Одесса : АтроПринт, 1999. - C. 240-243.

5. Voloshyna, I.S. (2011). Modern ideas about the morphogenesis of the internal organs of the male reproductive system under the influence of various factors. Ukrainian Morphological Almanac, 9, 4, 155-160 [in Ukrainian].

6. Mazur, O.O., Olenovych, O.A., Plaksyvyy, O.H., Kalutskyy, I.V., Yakovets, K.I., \& Bohach, V.A. (2017). Indicators of endogenous intoxication in patients with chronic purulent maxillary sinusitis with type 1 diabetes mellitus. Bukovinian Medical Bulletin, 21, 1 (81), 76-80 [in Ukrainian].

7. Klishch, I.M., \& Khorosh. V.Ya. (2013). Indicators of endogenous intoxication and humoral immunity in animals with chronic prostatitis and benign hyperplasia on the background of simultaneous exposure to toxic 
xenodermal extract. Medical Chemistry, 15 (1), 125-129 [in Ukrainian].

8. Lys, O.B., \& Reheda, M.S. (2019). The degree of endogenous intoxication in the dynamics of combined pathology -immobilization stress and adrenaline damage to the myocardium. Bulletin of Scientific Research, 1, 131-134 [in Ukrainian].

9. Khokhlova, N.I., Tolokonskaya, N.P., \& Pupyshev, A.B. (2011). Multifactor clinical and laboratory evaluation of endogenous intoxication in chronic hepatitis B. Bulletin of Siberian Medicine, 3, 139- 145 [in Russian].
10. Aksenova, M.V., Kuznetsov, V.F., \& Maslov, Yu.N. (2005). [Laboratory diagnosis of endogenous intoxication syndrome: Guidelines]. Perm: PGMA [in Russian].

11. Volchegorskiy, I., Dyatlov, D.A., \& Lvovskaya, Ye.I. (1996). [Medium molecules as probable regulators of the erythron system in skiers]. Human Physiology, 22 (3), 136-137 [in Russian].

12. Kazimirko, V.K., \& Maltsev, V.I. (2007). Antioxidant system and its functioning in the human body. Health of Ukraine, 5, 15-24 [in Russian].

13. Drannik, G.N. (1999). Clinical immunology and allergology. Odesa: AtroPrint [in Russian].

Yu. I. Makodrai, I. M. Klishch

I. HORBACHEVSKY TERNOPIL NATIONAL MEDICAL UNIVERSITY

\section{INDICATORS OF ENDOGENOUS INTOXICATION IN RATS WITH BENIGN PROSTATIC HYPERPLASIA UNDER TOXIC EFFECT OF ETHANOL}

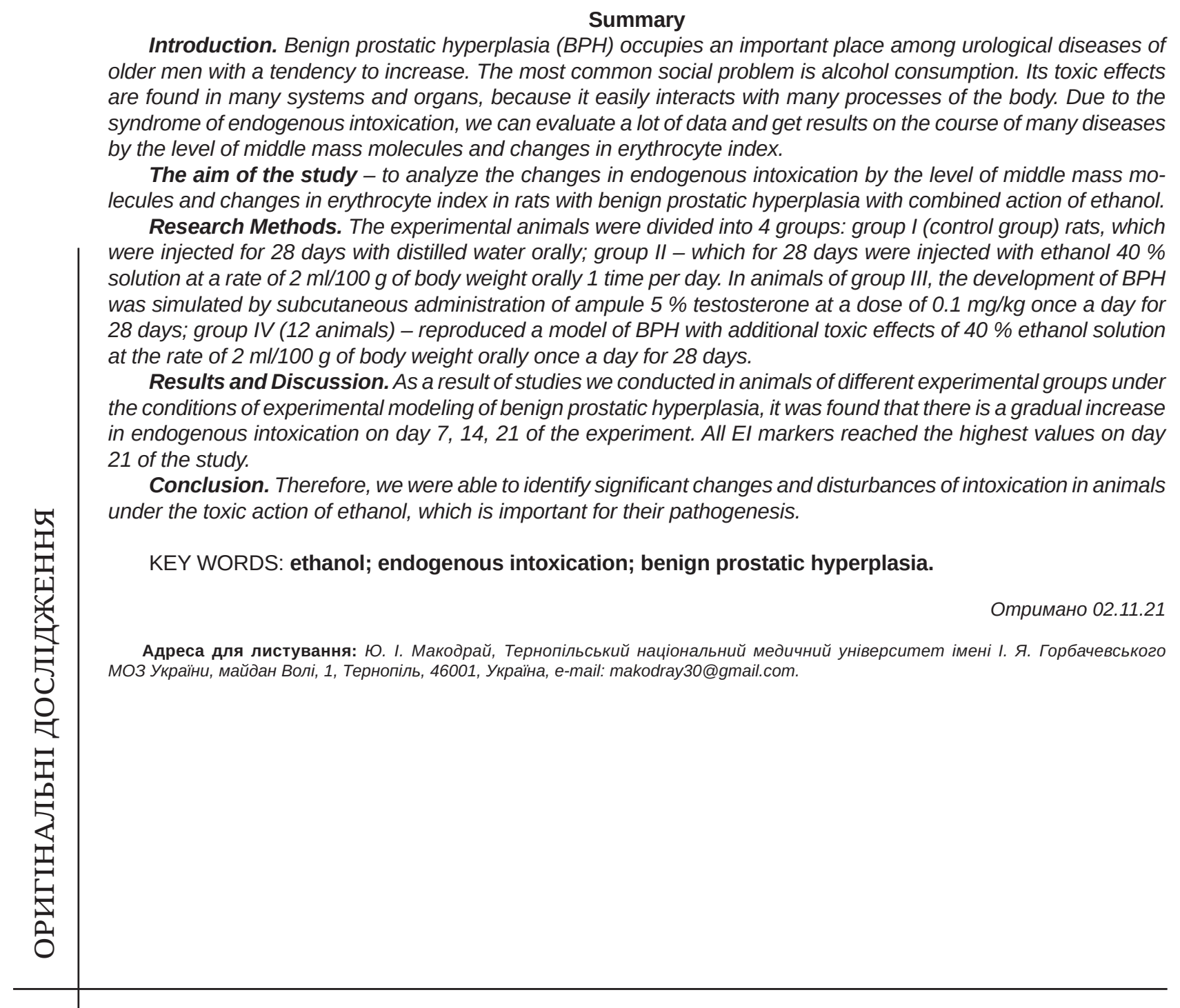

